\title{
Soil microbial population and yield of rainfed maize as affected by farmyard manure and biodigester liquid manure
}

\author{
K.P. Suresh Naik ${ }^{*}$, S. Narayana and T. Basavaraj Naik
}

\begin{abstract}
A field experiment was conducted during Kharif (June-October) season 2010, under rainfed condition on red sandy loam soil to study the effect of farmyard manure (FYM) and biodigester liquid manure (BDLM) on soil microbial activity and yield of rainfed maize (Zea mays L.). A total of 13 treatments were laid out in a randomized complete block design with three replicates. The treatment combinations comprised of different levels of FYM $(7.5,10$ and 12.5 t/ha) and BDLM-equivalent N (BDLME: 75, 100, 125 and $150 \mathrm{~kg} \mathrm{~N} / \mathrm{ha}$ ) compared with control [FYM 7.5 t ha ${ }^{-1}$ + recommended dose of chemical fertilizer (RDF): 100:50:25 kg $\mathrm{N}: \mathrm{P}: \mathrm{K} / \mathrm{ha}$ ]. Application of FYM (12.5 t/ha) + BDLME (150 kg N/ha) recorded a significantly higher microbial population in soil after crop harvest total bacteria $50.5 \times 10^{6} \mathrm{CFU} / \mathrm{g}$, fungi $26.0 \times 10^{4} \mathrm{CFU} / \mathrm{g}$, and actinomycetes $\left.23.8 \times 10^{3} \mathrm{CFU} / \mathrm{g}\right)$, grain yield and straw yield compared to the rest of the treatments. Application of FYM ( $7.5 \mathrm{t} / \mathrm{ha})+$ BDLME (75 kg N/ha) resulted in the lowest values for these parameters.
\end{abstract}

Keywords: Microbial population, biodigester liquid manure, farmyard manure, organic farming, rainfed maize

\section{Introduction}

Maize (Zea mays L.) is an important cereal due to its great production potential and adaptability to wide range of environments. Maize occupies a prime place in Indian economy, like rice, wheat and millets. In India, maize is grown in an area of $8.27 \mathrm{~m}$ ha with an annual production of about 17.3 million $t$. The average productivity of maize in India is about $2,091 \mathrm{~kg} \mathrm{ha}^{-1}$. In Karnataka, maize is cultivated in an area of 0.93 million ha producing 2.63 million $\mathrm{t}$ with a productivity of $2,970 \mathrm{Kg} \mathrm{ha}^{-1}$ (Anonymous, 2010). Currently, the agricultural research is focused on evolving ecologically sound, biologically sustainable and socio-economically viable technologies. Thus, application of farmyard manure (FYM) to the crops is being practiced. Addition of well decomposed farm yard manure to the soil not only supply plant nutrients, but also acts as binding material and improves the physical, chemical and biological properties of soil.

Similarly, application of biodigester liquid manure will increase the microbial populations. Hence, the potential of using FYM and biodigester liquid to supply nutrients and enhance beneficial microbes for faster decomposition is being recognized widely in field crops. The essence of practicing organic farming lies in the

\footnotetext{
Department of Agronomy, University of Agricultural Sciences, Bangalore, Karnataka, India

* Corresponding Author: sureshpnaik@gmail.com
} 
use of naturally available resources such as organic wastes, predators, and parasites in conjunction with natural processes like decomposition, biological fixation and resistance to achieve the needs of crop production. Most of the natural resources are useful only after they are microbiologically transformed to release the nutrients. Hence, organic farming is successful only when microbial population proliferates under suitable condition. This study focused on the potential use of FYM and biodigester liquid to supply nutrients and enhance beneficial microbes for faster decomposition in maize cultivation.

\section{Materials and Methods}

A Field experiment entitled was conducted during the Kharif (June-October) 2010 at the Agricultural Research Station, University of Agricultural Sciences (Bangalore), Tarikere taluk of the Chikkamagalure District in Karnataka. India. The soil of the experimental site was red sandy loam. The organic carbon content was $0.45 \%$. The available nitrogen was low (268.6 kg/ha), with moderate levels of phosphorus (23.6 $\mathrm{kg} / \mathrm{ha}$ ) and potassium ( $\left.154.5 \mathrm{~kg} \mathrm{ha}^{-1}\right)$. The experiment was laid out in randomized complete block design (RCBD) with 13 treatments with three replicates. Maize (Zea mays L.) hybrid Nithyashree (NAH-2049) was used as the test plant at a spacing of 45 $\mathrm{cm} \times 30 \mathrm{~cm}$. The treatment structure is shown in Tables 1 and 2. Farmyard manure (FMY) and biodigester liquid manure-equivalent (BDLME) were the organic supplements. The control plots received FYM 7.5 t/ha + recommended dose of chemical fertilizer (RDF): 100:50:25 kg N:P:K/ha).

A soil pit at the dimension of $10 \mathrm{~m} \times 5 \mathrm{~m} \times 1 \mathrm{~m}$ (length $\times$ width $\times$ height) was created by excavation of soil. The pit was reinforced using cement concrete for the floor and brick and mortar for walls to convert it to a biodigestor tank. Slope of the floor was made in two directions to facilitate the collection of liquid manure in the collection pit. Cattle shed washings and other liquid organic wastes were collected in the biodigestor tank. Crop residues such as maize husk, cob sheaths, haulms, ear heads, pith, straws, coconut fronds, etc., along with weeds were digested along with the cattle shed washings, cattle urine and some quantity of dung. Water was allowed just to reduce the volatilisation losses from the biodigester liquid.

The liquid residue was collected in the bottom corner side of the biodigester tank and the liquid residue manure was used for field application. The biodigester liquid manure was analyzed for its $\mathrm{N}$ content prior to application. On the basis of $\mathrm{N}$ content, the required quantity of biodigester liquid at 1:4 dilutions (Biodigester:water) was applied to all treatments except $T_{13}$ treatment (RDF: control). Biodigester liquid was applied to the soil in open furrows $10 \mathrm{~cm}$ away from the crop row at two times, i.e., at 30 and 45 days after sowing (DAS). Welldecomposed farmyard manure (FMY) was incorporated to the soil three weeks prior to sowing of maize seeds. 


\section{Microbial analysis of the soil sample before and after the crop harvest}

The microbial population in the soil after harvest of the crop was determined by the serial dilution plate count method. Soil samples from different treatments were collected separately in all replicates and pooled. Ten grams of pooled soil in each treatment was mixed in $90 \mathrm{~mL}$ of sterilized water blank to give a $10^{-1}$ dilution. Subsequent dilutions up to $10^{6}$ were made by transferring serially one $\mathrm{mL}$ of each dilution to nine $\mathrm{mL}$ sterilized water blanks. The population of total bacteria, fungi and actinomycetes were estimated by plating on appropriate media viz., soil extract agar, Martins Rose Bengal Streptomycin sulphate agar, and Kustras agar, respectively. The inoculated plates were kept for incubation at $30{ }^{\circ} \mathrm{C} \pm 1{ }^{\circ} \mathrm{C}$ for a week and emerged colonies were counted.

\section{Results and Discussion}

Among the different treatments, significantly higher number of microbial population $(p<0.05)$ was recorded in the application of FYM $(12.5 \mathrm{t} / \mathrm{ha})+$ biodigester liquid manure equivalent (BDLME) of $150 \mathrm{~kg} \mathrm{~N} / \mathrm{ha}$ (Table 1) and grain yield and straw yield (Table 2).

Table 1. Microbial population (initial and after harvest) as influenced by different levels of FYM and biodigester liquid manure (BDKM) under rainfed condition

\begin{tabular}{|c|c|c|c|}
\hline Treatments & $\begin{array}{c}\text { Bacteria } \\
\left(\text { No. } \times 10^{6}\right. \\
\text { CFU/g) }\end{array}$ & $\begin{array}{c}\text { Fungi } \\
\left(\text { No. } \times 10^{4}\right. \\
\text { CFU/g) }\end{array}$ & $\begin{array}{c}\text { Actinomycetes } \\
\left(\text { No. } \times 10^{3}\right. \\
\text { CFU/g) }\end{array}$ \\
\hline $\mathrm{T}_{1}: \mathrm{FYM}^{1}(7.5 \mathrm{t} / \mathrm{ha})+\mathrm{BDLME}^{2}(75 \mathrm{~kg} \mathrm{~N} / \mathrm{ha})$ & 32.3 & 13.8 & 9.5 \\
\hline $\mathrm{T}_{2}: \mathrm{FYM}(7.5 \mathrm{t} / \mathrm{ha})+\mathrm{BDLME}(100 \mathrm{~kg} \mathrm{~N} / \mathrm{ha})$ & 33.2 & $14 \cdot 3$ & 10.7 \\
\hline $\mathrm{T}_{3}: \mathrm{FYM}(7.5 \mathrm{t} / \mathrm{ha})+\mathrm{BDLME}(125 \mathrm{~kg} \mathrm{~N} / \mathrm{ha})$ & 35.0 & $15 \cdot 3$ & 11.8 \\
\hline $\mathrm{T}_{4}: \mathrm{FYM}(7.5 \mathrm{t} / \mathrm{ha})+\mathrm{BDLME}(150 \mathrm{~kg} \mathrm{~N} / \mathrm{ha})$ & 42.3 & 16.7 & 15.2 \\
\hline $\mathrm{T}_{5}: \mathrm{FYM}(10 \mathrm{t} / \mathrm{ha})+\mathrm{BDLME}(75 \mathrm{~kg} \mathrm{~N} / \mathrm{ha})$ & 34.7 & 14.7 & 11.7 \\
\hline $\mathrm{T}_{6}: \mathrm{FYM}(10 \mathrm{t} / \mathrm{ha})+\mathrm{BDLME}(100 \mathrm{~kg} \mathrm{~N} / \mathrm{ha})$ & 36.2 & $15 \cdot 5$ & 11.6 \\
\hline $\mathrm{T}_{7}: \mathrm{FYM}(10 \mathrm{t} / \mathrm{ha})+$ BDLME (125 kg N/ha) & 37.8 & 18.8 & $15 \cdot 5$ \\
\hline $\mathrm{T}_{8}: \mathrm{FYM}(10 \mathrm{t} / \mathrm{ha})+\mathrm{BDLME}(150 \mathrm{~kg} \mathrm{~N} / \mathrm{ha})$ & 48.1 & 23.9 & 22.3 \\
\hline $\mathrm{T}_{9}: \mathrm{FYM}(12.5 \mathrm{t} / \mathrm{ha})+\mathrm{BDLME}$ (75 kg N/ha) & 36.7 & 16.0 & 15.0 \\
\hline $\mathrm{T}_{10}: \mathrm{FYM}(12.5 \mathrm{t} / \mathrm{ha})+$ BDLME (100 kg N/ha) & 40.5 & 17.8 & 16.8 \\
\hline $\mathrm{T}_{11}: \mathrm{FYM}(12.5 \mathrm{t} / \mathrm{ha})+\mathrm{BDLME}(125 \mathrm{~kg} \mathrm{~N} / \mathrm{ha})$ & 41.3 & $19 \cdot 3$ & 17.2 \\
\hline $\mathrm{T}_{12}: \mathrm{FYM}(12.5 \mathrm{t} / \mathrm{ha})+\mathrm{BDLME}(150 \mathrm{~kg} \mathrm{~N} / \mathrm{ha})$ & 50.5 & 26.0 & 23.8 \\
\hline $\mathrm{T}_{13}{ }^{3}: \mathrm{FYM}(7.5 \mathrm{t} / \mathrm{ha})+\mathrm{RDF}^{4}: 100: 50: 25 \mathrm{~kg} \mathrm{~N}: \mathrm{P}: \mathrm{K} / \mathrm{ha}$ & 46.8 & 22.8 & 20.9 \\
\hline S.E. $(m)^{5}$ & 1.65 & 1.98 & 1.05 \\
\hline C.D. ${ }^{6}(p=0.05)$ & 4.87 & 5.86 & 3.11 \\
\hline Initial population & 31.3 & 18.4 & 14.8 \\
\hline
\end{tabular}

1 = Farmyard manure, 2 = Biodigester liquid manure equivalent, $3=$ Control, 4 = recommended dose of chemical fertilizer, $5=$ standard error of the mean, $6=$ critical difference 
The FYM and BDLM which may have improved the activity of beneficial microorganisms, increased the organic carbon, increased the availability of $\mathrm{N}, \mathrm{P}$ and $\mathrm{K}$ in soil and thus, higher grain weight of rainfed maize. Higher leaf area and dry matter accumulation in leaves, coupled with better translocation of photosynthates to seed would have helped overall seed development and bolder seeds thus recorded higher grain weight.

Table 2. Grain yield and stover yield of maize as influenced by different levels of farmyard manure and biodigester liquid manure under rainfed condition

\begin{tabular}{|c|c|c|}
\hline Treatments & $\begin{array}{c}\text { Grain yield } \\
(\mathrm{t} / \mathrm{ha})\end{array}$ & $\begin{array}{l}\text { Stover yield } \\
(\mathrm{t} / \mathrm{ha})\end{array}$ \\
\hline $\mathrm{T}_{1}: \mathrm{FYM}^{1}(7.5 \mathrm{t} / \mathrm{ha})+\mathrm{BDLME}^{2}(75 \mathrm{~kg} \mathrm{~N} / \mathrm{ha})$ & 4.22 & 8.54 \\
\hline $\mathrm{T}_{2}: \mathrm{FYM}(7.5 \mathrm{t} / \mathrm{ha})+\mathrm{BDLME}(100 \mathrm{~kg} \mathrm{~N} / \mathrm{ha})$ & 4.26 & 8.70 \\
\hline $\mathrm{T}_{3}: \mathrm{FYM}(7.5 \mathrm{t} / \mathrm{ha})+\mathrm{BDLME}(125 \mathrm{~kg} \mathrm{~N} / \mathrm{ha})$ & 4.40 & 9.09 \\
\hline $\mathrm{T}_{4}: \mathrm{FYM}(7.5 \mathrm{t} / \mathrm{ha})+\mathrm{BDLME}(150 \mathrm{~kg} \mathrm{~N} / \mathrm{ha})$ & 4.62 & 9.70 \\
\hline $\mathrm{T}_{5}: \mathrm{FYM}(10 \mathrm{t} / \mathrm{ha})+\mathrm{BDLME}(75 \mathrm{~kg} \mathrm{~N} / \mathrm{ha})$ & 4.33 & 8.84 \\
\hline $\mathrm{T}_{6}: \mathrm{FYM}(10 \mathrm{t} / \mathrm{ha})+\mathrm{BDLME}(100 \mathrm{~kg} \mathrm{~N} / \mathrm{ha})$ & 4.47 & $9 \cdot 38$ \\
\hline $\mathrm{T}_{7}: \mathrm{FYM}(10 \mathrm{t} / \mathrm{ha})+\mathrm{BDLME}(125 \mathrm{~kg} \mathrm{~N} / \mathrm{ha})$ & 4.69 & 9.70 \\
\hline $\mathrm{T}_{8}: \mathrm{FYM}(10 \mathrm{t} / \mathrm{ha})+\mathrm{BDLME}(150 \mathrm{~kg} \mathrm{~N} / \mathrm{ha})$ & 5.51 & 10.70 \\
\hline $\mathrm{T}_{9}: \mathrm{FYM}(12.5 \mathrm{t} / \mathrm{ha})+\mathrm{BDLME}(75 \mathrm{~kg} \mathrm{~N} / \mathrm{ha})$ & 4.52 & 9.49 \\
\hline $\mathrm{T}_{10}:$ FYM (12.5 t/ha) + BDLME (100 kg N/ha) & 4.80 & 9.95 \\
\hline $\mathrm{T}_{11}: \mathrm{FYM}(12.5 \mathrm{t} / \mathrm{ha})+\mathrm{BDLME}(125 \mathrm{~kg} \mathrm{~N} / \mathrm{ha})$ & 5.00 & 10.07 \\
\hline $\mathrm{T}_{12}: \mathrm{FYM}(12.5 \mathrm{t} / \mathrm{ha})+$ BDLME (150 kg N/ha) & 5.62 & 10.89 \\
\hline $\mathrm{T}_{13}^{3}: \mathrm{FYM}(7.5 \mathrm{t} / \mathrm{ha})+\mathrm{RDF}^{4}: 100: 50: 25 \mathrm{~kg} \mathrm{~N}: \mathrm{P}: \mathrm{K} / \mathrm{ha}$ & 5.42 & 10.57 \\
\hline S.E. $(m)^{5}$ & 0.14 & 0.12 \\
\hline C.D. ${ }^{6}(p=0.05)$ & 0.42 & 0.35 \\
\hline
\end{tabular}

1 = Farmyard manure, 2 = Biodigester liquid manure equivalent, $3=$ Control, $4=$ recommended dose of chemical fertilizer, $5=$ standard error of the mean, $6=$ critical difference

These results are in accordance with Sharma and Dixit (1987), Kandeler et al. (1999) and Ravikumar (2009). The results were also statistically in par ( $>>0.05)$ with the treatment FYM (10 t/ha) + BDLME of (150 kg N/ha). Lower microbial populations, grain yield and straw yield was recorded with the application of FYM (7.5 t/ha + BDLME of (75 kg N/ha), probably due low organic matter content and less favorable soil condition resulting in lesser microbial activity, as explained by Badole and More (2001) and Naveenkumar (2009).

\section{Acknowledgement}

The first author is thankful to the Directorate of Research of the University of Agricultural Sciences, GKVK, Bangaluru, India for providing financial assistance under the RKVY Project scheme. Guidance provided by Dr. Narayana S. Mavarkar is gratefully acknowledged. 


\section{References}

Anonymous. (2010): Annual Report, published by Department of Agriculture and Cooperation, GOI, New Delhi.

Badole, S. and More, S.D. (2001): Residual effect of integrated nutrient management on yield of groundnut. J. Maharashtra., 26(1): 109-110.

Kandeler, E., Stemmeer, M. and Mariacklicmanek, E. (1999): Response of soil microbial biomass, urease and xylanase within particle size fractions to long-term soil management. Soil Biol. Biochem., 31(2): 261-273.

Naveenkumar, A.T. (2009): Effect of FYM and Biodigested liquid manure on growth and yield of groundnut under rainfed condition, M.Sc. (Agri.) Thesis, Univ. Agric. Sci. Bangalore, Karnataka, India.

Ravikumar, H.S. (2009): Effect of FYM and Biodigested liquid manure on growth and yield of groundnut under rainfed condition. M. Sc. (Agri.) Thesis, Univ. Agric. Sci., Bangalore, India.

Sharma, R.A. and Dixit, B.K. (1987): Effect of nutrient application on rainfed soybean. J. Indian Soc. Soil Sci., 35(3): 452:455. 
Suresh Naik et al. 